\section{Preparation and catalytic evaluation of ruthenium-nickel dendrimer encapsulated nanoparticles via intradendrimer redox displacement of nickel nanoparticles $\dagger$}

\author{
Katherine A. Marvin, ${ }^{a}$ Nicole N. Thadani, ${ }^{b}$ Corinne A. Atkinson, ${ }^{c}$ Emily L. Keller ${ }^{c}$ and \\ Keith J. Stevenson $\%$
}

Received 24th February 2012, Accepted 1st May 2012

DOI: $10.1039 / \mathrm{c} 2 \mathrm{cc} 31370 \mathrm{~g}$

$\mathrm{Ru}$ and $\mathrm{Ru}_{\mathrm{x}} \mathrm{Ni}_{30}$ dendrimer encapsulated nanoparticles (DENs) were synthesized using a redox-displacement method. DEN catalytic activity for the reduction of $p$-nitrophenol was evaluated and found to be dependent on the ratio of metals present.

Dendrimer-templated nanoparticle synthesis is an efficient method for preparing a variety of mono- and bimetallic nanomaterials, whose sizes are constrained by the loading capacity of the dendrimer template. ${ }^{1,2}$ A common commercially available dendrimer is composed of repeating amino-amide units (polyamidoamine, PAMAM), whose internal amines coordinate with free metal ions in solution. ${ }^{3}$ The metal ion affinity for these amine groups strongly influences their partitioning into the dendrimer interior; metal ions such as $\mathrm{Cu}^{2+}$ and $\mathrm{Pd}^{2+}$ will readily complex within dendrimers under the appropriate conditions and may be directly reduced to metal nanoparticles. ${ }^{4,5}$ However, weakly coordinating metal ions require either a dendrimer template with more appropriate interior groups for coordinating metal cations, which may not be readily available, or an indirect synthetic route. Intradendrimer redox displacement, which involves the formation of dendrimer encapsulated nanoparticles (DENs) of one metal followed by exchange for a second, more noble metal, has been previously reported. ${ }^{6}$ Zhao et al. ${ }^{6}$ synthesized $\mathrm{Cu}_{55}$ DENs using generation 6 , hydroxyl-terminated (G6-OH) PAMAM dendrimers. Galvanic displacement of $\mathrm{Cu}^{0}\left(E_{\mathrm{Ox}}=-0.342 \mathrm{~V}\right)$ with $\mathrm{Ag}^{+}$to form $\mathrm{Ag}^{0}$ $\left(E_{\text {red }}=0.777 \mathrm{~V}\right)$ was then performed. Subsequent displacement of $\mathrm{Ag}^{0}$ with $\mathrm{Pd}^{2+}, \mathrm{Pt}^{2+}$ and $\mathrm{Au}^{3+}$ to form the corresponding DENs can also be accomplished.

${ }^{a}$ Department of Chemistry, 201 Donaghey Avenue, University of Central Arkansas, Conway, Arkansas 72035, USA.

E-mail:kmarvin@uca.edu; Fax: 501-450-3623; Tel: 501-852-8282

${ }^{b}$ California Institute of Technology, 200 East California Boulevard, Pasadena, California 91125,USA.E-mail: nikki@caltech.edu

${ }^{c}$ Department of Chemistry and Biochemistry, 1 University Station A5300, The University of Texas at Austin, Austin, Texas, USA.

E-mail: stevenson@cm.utexas.edu; Fax: 512-471-6835;

Tel: 512-232-9160

$\dagger$ Electronic supplementary information (ESI) available: TEM images and EDS data for G4-OH( $\left(\mathrm{Ru}_{20}\right)$ DENs. UV-Visible characterization of the DEN-catalyzed reduction of $p$-nitrophenol. See DOI: 10.1039 / c2 $\operatorname{cc} 31370 \mathrm{~g}$
Here, we describe the preparation of ruthenium-nickel dendrimer encapsulated nanoparticles (RuNi DENs) in generation 4 hydroxylterminated (G4-OH) PAMAM dendrimers. Previously reported syntheses of $\mathrm{Ru}$ DENs used sodium borohydride $\left(\mathrm{NaBH}_{4}\right)^{7}$ as well as $\mathrm{H}_{2(\mathrm{~g})}{ }^{8}$ as reductants, following complexation of the $\mathrm{Ru}^{3+}$ for $2-3$ days. In this report, we investigated $\mathrm{Ni}$ as a potential partner in a displacement scheme to form $\mathrm{Ru}$ and RuNi DENs; the displacement was evaluated for 5-20 molar excess (ME) of $\mathrm{Ru}^{3+}$ and $\mathrm{Ni}^{2+}$, and the resulting effects on the DEN catalytic efficiency for a model reduction reaction were evaluated. This method of preparation eliminates significant metal ion complexation time and results in RuNi DENs that are stable for at least a week under an inert atmosphere.

The galvanic displacement of $\mathrm{Ni}^{0}$ with $\mathrm{Ru}^{0}$ is based on the following set of half-reactions: ${ }^{9}$

$$
\begin{gathered}
3 \mathrm{Ni}^{0} \rightarrow 3 \mathrm{Ni}^{2+}+6 \mathrm{e}-+0.257 \mathrm{~V} \\
2 \mathrm{Ru}^{3+}+6 \mathrm{e}-\rightarrow 2 \mathrm{Ru}^{0}+0.704 \mathrm{~V} \\
3 \mathrm{Ni}^{0}+2 \mathrm{Ru}^{3+} \rightarrow 3 \mathrm{Ni}^{2+}+2 \mathrm{Ru}^{0}+0.961 \mathrm{~V}
\end{gathered}
$$

During synthesis, $30 \mathrm{ME}$ of $\mathrm{Ni}\left(\mathrm{NO}_{3}\right)_{2}$ was added to a $10 \mu \mathrm{M}$ aqueous solution of G4-OH PAMAM dendrimer at $\mathrm{pH} \sim 5$ and placed on a VWR nutating mixer. After 60-90 min, the UV-Visible absorption spectrum showed a very weak band at $272 \mathrm{~nm}$ and no bands associated with $\mathrm{Ni}^{2+}$ in solution, indicating that $\left(\mathrm{Ni}^{2+}\right)_{30}$ was complexed within the dendrimer interior (Fig. 1A). After purging with $\operatorname{Ar}_{(\mathrm{g})}$ for $20 \mathrm{~min}$, the solution was reduced with $5 \mathrm{ME}$ of $\mathrm{NaBH}_{4}$; the colorless solution turned translucent brown, the spectrum shifted upward, and the distinctive peak at $272 \mathrm{~nm}$ flattened. The solution $\mathrm{pH}$ was adjusted to $\leq 8$ using $\sim 0.010 \mathrm{~mL}$ (per mL of solution) of $0.10 \mathrm{M} \mathrm{HCl}$ via a gas-tight syringe; the approximate solution $\mathrm{pH}$ was checked using pHydrion paper. The solution was gently purged a second time to remove all residual reductant, and the desired $\mathrm{ME}$ of Ar-purged $\mathrm{RuCl}_{3}$ solution was added drop-wise to the solution with mixing. Over a period of several minutes, the absorbance at wavelengths below $500 \mathrm{~nm}$ increase in intensity slightly, and a peak at $\sim 279 \mathrm{~nm}$ with a broad shoulder at $\sim 318 \mathrm{~nm}$ is observed. These spectral features are consistent 

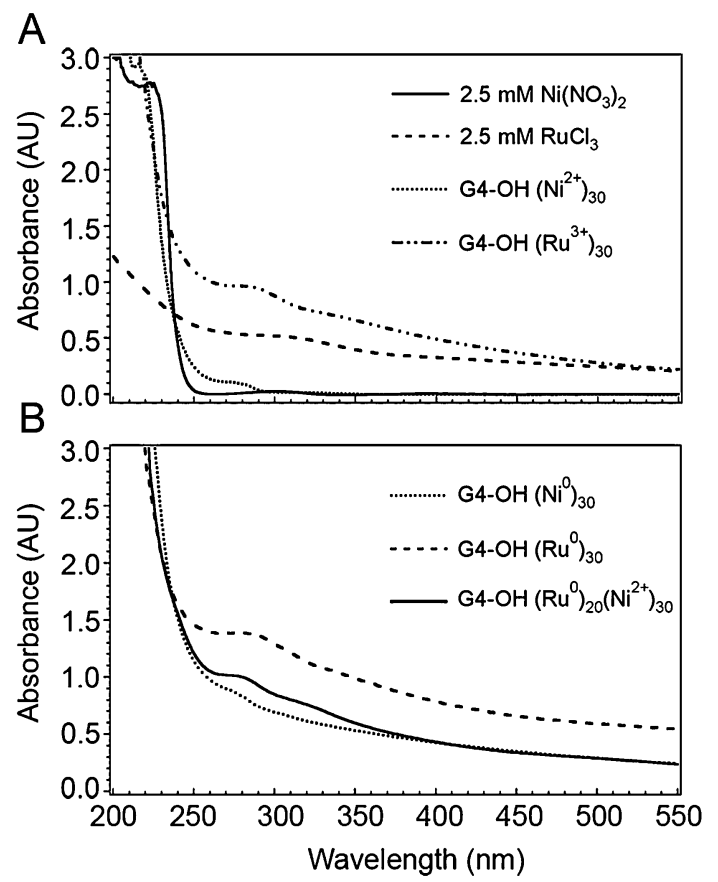

Fig. 1 UV-Visible absorption spectra of the uncomplexed and complexed $\mathrm{Ni}^{2+}$ and $\mathrm{Ru}^{3+}$ in the G4-OH dendrimer template (A), and comparison of the formation of $\mathrm{G} 4-\mathrm{OH} \mathrm{Ru} \mathrm{Ru}_{20}\left(\mathrm{Ni}^{2+}\right)_{30}$ DENs via direct reduction and $\mathrm{Ni}^{0}$ displacement (B).

with those we observed when an anaerobic solution of G4-OH $\left(\mathrm{Ru}^{2+}\right)_{30}$ was reduced with $20 \mathrm{ME}$ of $\mathrm{NaBH}_{4}$ (Fig. 1B). Transmission electron microscopy (TEM) images and energy dispersive X-ray spectroscopy data (EDS) of the G4-OH $\mathrm{Ru}_{20}\left(\mathrm{Ni}^{2+}\right)_{30}$ DENs were collected. Analysis of TEM images showed an average particle size of $1.0 \pm 0.1 \mathrm{~nm}$ with an estimated 1:1 Ru: Ni metal ratio, though the extent of clustering made particles difficult to isolate for single particle EDS analysis (Supplementary Information Fig. S1 and S2 $\dagger$ ).

Each of the prepared DENs was then evaluated as a catalyst for the reduction of $p$-nitrophenol ( $p$-NP). At alkaline $\mathrm{pH}, p$-NP is highly colored, and reduction to the colorless $p$-aminophenol occurs very slowly in the presence of excess $\mathrm{NaBH}_{4}$ but may be increased several orders of magnitude using a catalyst. ${ }^{10,11}$ This reaction may be followed as the intensity at $400 \mathrm{~nm}(p$-NP) decreases (Supplementary Information Fig. S3†). The rate of reduction has been observed to be pseudo-first order in the presence of a large $\mathrm{ME}$ of $\mathrm{NaBH}_{4}$ :

$$
\text { Rate }=k[p-\mathrm{NP}]
$$

where the concentration of $p$-NP is directly related to the absorbance at $400 \mathrm{~nm}$ via Beer's Law:

$$
\mathrm{A}=\varepsilon \mathrm{lC}
$$

The rate constant, $k\left(\mathrm{~s}^{-1}\right)$, of the reaction is determined by plotting the corrected natural $\log$ of the Absorbance 400 vs. time (s) via the first order integrated rate law:

$$
\ln \left[\mathrm{Abs}_{400}\right]=-k \mathrm{t}+\ln \left[\mathrm{Abs}_{400}\right]_{t=0}
$$

$\mathrm{Abs}_{400}$ values used to determine rate constants were baseline corrected; the baseline absorbance at $600 \mathrm{~nm}$ was subtracted from the raw $\mathrm{Abs}_{400}$ value, giving $\mathrm{Abs}_{(400-600)}$. The minimum value of $\mathrm{Abs}_{(400-600)}$ was then subtracted from each $\mathrm{Abs}_{(400-600)}$ to give the final, baseline corrected $\mathrm{Abs}_{400}$ value. Kinetic experiments were performed using Ar-purged solutions and septa-sealed polystyrene cuvettes to maintain anaerobic conditions for the air-sensitive $\mathrm{Ru}-\mathrm{Ni}$ DENs.

When the reduction of $p$-NP is catalyzed by the individual monometallic G4-OH $\mathrm{Ru}_{30}$ or $\mathrm{Ni}_{30}$ DENs, a significant difference in catalytic activity is noted (Table 1). G4-OH Ru $\mathrm{Ru}_{30}$ DENs exhibited very low to negligible catalytic activity under these reaction conditions $\left(<0.003 \mathrm{~s}^{-1}\right)$; in contrast, G4-OH Ni ${ }_{30}$ DENs exhibited a high relative efficiency, but were found to demonstrate zero-order behavior for the $p$-NP reaction, with an observed average rate constant of $\sim 0.22 \mathrm{~s}^{-1}$ derived from the linear correlation of the final, corrected $\mathrm{Abs}_{400}$ vs. time (s).

Following redox displacement of $\mathrm{Ni}$ to form bimetallic $\mathrm{Ru}_{\mathrm{x}} \mathrm{Ni}_{30}$ DENs, it is expected that the displaced, oxidized $\mathrm{Ni}^{2+}$ metal ions will remain complexed within the dendrimer as long as the $\mathrm{pH}$ is high enough to prevent $\mathrm{H}^{+}$competition for interior amine sites. In addition, the terminal $-\mathrm{OH}$ groups are not expected to complex with $\mathrm{Ni}^{2+}$, making the formation of intradendrimer particles unlikely. The absorption features of $\mathrm{Ru}^{0}$ within the dendrimer obscure spectral features that would indicate the presence of $\mathrm{Ni}^{2+}$ ions in solution; however, when the reduction of $p$-NP was initiated with an excess of $\mathrm{NaBH}_{4}$, precipitation was not observed, which is consistent with the formation of fully reduced bimetallic particles, e.g., $\mathrm{Ru}_{5} \mathrm{Ni}_{30}$, present as the catalyst. However, the formation of nickel oxides cannot be ruled out.

The collected kinetic data for the selected combinations of $\mathrm{Ru}_{\mathrm{x}} \mathrm{Ni}_{30}$ indicate that the ME of $\mathrm{Ru}$ present in the DEN may be correlated to the magnitude of the observed rate constant, $k\left(\mathrm{~s}^{-1}\right)$ (Table 1). $\mathrm{Ru}_{\mathrm{x}} \mathrm{Ni}_{30}$ DENs exhibit first-order behavior as well as variable, and significant, increases in the rate constant as compared to either of the monometallic $\mathrm{Ru}$ or Ni DENs. A maximum average rate is observed for G4-OH $\mathrm{Ru}_{10} \mathrm{Ni}_{30}$ DENs at $2.21 \mathrm{~s}^{-1}$, and each of the other DEN combinations of $\mathrm{Ru}$ and $\mathrm{Ni}$ exhibit altered catalytic activity, with the smallest rate observed for nickel-enriched $\mathrm{Ru}_{5} \mathrm{Ni}_{30}$ DENs at $0.96 \mathrm{~s}^{-1}$. It is worth noting that the optimal catalyst, $\mathrm{Ru}_{10} \mathrm{Ni}_{30}$, outperformed the best monometallic catalyst $\left(\mathrm{Pd}_{30}\right)$ we have tested in this size regime (Table $\mathrm{S} 1 \dagger$ ).

In conclusion, a redox-displacement method was employed to prepare $\mathrm{Ru}$ and $\mathrm{Ru}_{\mathrm{x}} \mathrm{Ni}_{30}$ dendrimer-encapsulated nanoparticles (DENs). The catalytic activities of alloys containing variable

Table 1 Comparison of the observed kinetic rate constants $\left(k, \mathrm{~s}^{-1}\right)$ using $\mathrm{Ru}, \mathrm{Ni}$ and RuNi DENs. All solutions were $\operatorname{Ar}_{(\mathrm{g})}$-purged, and each kinetic trial was prepared by adding $1.75 \mathrm{~mL}$ of nanopure water and $0.2 \mathrm{~mL}$ of $600 \mu \mathrm{M} p$-NP ( $\mathrm{pH} \sim 12)$ to the septum-sealed polystyrene cuvette via gas-tight syringe; $0.6 \mathrm{~mL}$ of $0.2 \mathrm{M} \mathrm{NaBH}_{4}$ was then added to the cuvette, and the reaction was initiated by injecting $0.4 \mathrm{~mL}$ of $10 \mu \mathrm{M}$ DEN solution into the stirred solution. Kinetics were monitored using UV-vis spectrophotometry (Ocean Optics USB4000, LoggerPro 3.8)

\begin{tabular}{ll}
\hline $\mathrm{DEN}$ & Rate constant, $k_{\text {avg }}, \mathrm{s}^{-1}$ \\
\hline $\mathrm{Ru}_{30}$ & $<0.003$ \\
$\mathrm{Ni}_{30}$ & $0.22 \pm 0.05$ \\
$\mathrm{Ru}_{5} \mathrm{Ni}_{30}$ & $0.95 \pm 0.03$ \\
$\mathrm{Ru}_{10} \mathrm{Ni}_{30}$ & $2.21 \pm 0.11$ \\
$\mathrm{Ru}_{15} \mathrm{Ni}_{30}$ & $1.84 \pm 0.02$ \\
$\mathrm{Ru}_{20} \mathrm{Ni}_{30}$ & $1.45 \pm 0.03$ \\
\hline
\end{tabular}


$\mathrm{Ru}$ : Ni ratios were evaluated and found to reach a maximum at an intermediate molar ratio of $\mathrm{Ru}: \mathrm{Ni}$ metals.

This work is supported by the Freshman Research Initiative (FRI) within the College of Natural Sciences at the University of Texas at Austin. We acknowledge the NSF (0629136), HHMI (52005907) and Norman Hackerman Advanced Research Program (003658-0030-2009) for finanicial support, and we also acknowledge Dendritech, Inc. for their generous donation of the G4-OH PAMAM dendrimer reagent. We thank Stacia Rodenbusch for assistance with the preparation of this manuscript.

\section{References}

1 R. W. J. Scott, O. M. Wilson and R. M. Crooks, J. Phys. Chem. B, 2005, 109, 692 .
2 X. Peng, Q. Pan and G. L. Rempel, Chem. Soc. Rev., 2008, 37, 1619.

3 D. A. Tomalia, H. Baker, J. Dewald, M. Hall, G. Kallos, S. Martin, J. Roeck, J. Ryder and P. Smith, Polym. J., 1985, $17,117$.

4 M. Zhao and R. M. Crooks, Angew. Chem., Int. Ed., 1999, 38, 364. 5 M. Zhao, L. Sun and R. M. Crooks, J. Am. Chem. Soc., 1998, 120, 4877.

6 M. Zhao and R. M. Crooks, Chem. Mater., 1999, 11, 3379.

7 I. L. Escalante-García, J. Ledesma-García, F. J. Rodríguez, T. W. Chapman and L. A. Godínez, ECS Trans., 2007, 3, 1.

8 G. Lafaye, C. T. Williams and M. D. Amiridis, Catal. Lett., 2004, 96, 43.

9 A. J. Bard, Encyclopedia of electrochemistry of the elements, Marcel Dekker, Inc, New York, 1978.

10 T. Endo, T. Yoshimura and K. Esumi, J. Colloid Interface Sci., 2005, 286, 602.

11 N. Pradhan, A. Pal and T. Pal, Colloids Surf., A, 2002, 196, 247. 